\title{
Iron-stress in phytoplankton determined by ELISA test
}

\author{
L.A. Inda ${ }^{1}$ \\ M.J. Gil ${ }^{2}$ \\ M.L. Peleato ${ }^{1}$
}

Keywords : ELISA, ferredoxin, flavodoxin, iron-stress.

Flavodoxin and ferredoxin can be used as molecular markers for determination of biolimitation of iron in phytoplankton. Two ELISA tests have been used for determination of flavodoxin and ferredoxin respectively in samples from three endorheic lagoons.

\section{Détermination de l'impact du fer dans la biolimitation du phytoplancton par le test ELISA}

Mots-clés : ELISA, ferredoxine, flavodoxine, stress ferrique.

La flavodoxine et la ferredoxine peuvent être utilisées comme marqueurs moléculaires pour déterminer le rôle du fer dans la limitation du phytoplancton. Deux tests ELISA ont été réalisés dans le but de quantifier la flavodoxine et la ferredoxine dans des échantillons provenant de trois lagunes endorhéiques.

\section{Introduction}

Iron availability and biolimitation by iron has been an important focus of discussion for oceanographers, and after the IronEX II (Coale et al. 1996, Behrenfeld et al. 1996, Kirchman 1996) it was definitively established that availability of iron unequivocally limits cell division rates, abundance and production rate in phytoplankton (Frost 1996). The evaluation of the iron nutritional status of the phytoplankton has been an issue of great interest, not only for the oceans but also for continental waters, where toxin production (Utkilen \& Gjolme 1995) or undesirable blooms can be related with iron availability. Direct measures of iron are not a good indication of the nutritional status of the organisms, since the-biodisponibility is affected by environmental (oxygen, pH...) or biological factors. Iron is not a common parameter measured by limnologist, but

\footnotetext{
1. Departamento de Bioquímica, Facultad de Ciencias, Universidad de Zaragoza, 50009 Zaragoza, Spain.

2. Departamento de Didáctica de las Ciencias Experimentales, Universidad de Zaragoza, 50009 Zaragoza, Spain.
}

the interest in their possible role as limiting element is increasing.

Flavodoxin has been proposed for use as a suitable marker for evaluating the iron nutritional status of the phytoplankton in high-nutrient low-chlorophyll oceanic regions (La Roche et al. 1996). Flavodoxin is an small flavoprotein induced as consequence of iron starvation and replaces ferredoxin in the photosynthetic electron chain. Anderson group (Doucette et al. 1996) proposed as diagnostic indicator of iron stress the relative abundance of flavodoxin, as a percentage of the combined pool of flavodoxin and ferredoxin (Flavodoxin Index). The flavodoxin Index corrects the heterogeneity of the flavodoxin induction among the organisms, with presence of constitutive flavodoxin in several cases (Entsch et al. 1983).

The current methods for evaluating flavodoxin and ferredoxin are HPLC (Doucette et al. 1996) and semiquantitative Western blotts (La Roche et al. 1995, La Roche et al. 1996). HPLC methods achieved a sensibility of $1 \mu \mathrm{g} / \mathrm{ml}$ on crude extracts (Doucette et al. 1996), requiring a considerable amount of cells with large sampling. Using the HPLC and spectrophotometric detection, the determination involves all the flavodoxins 
or ferredoxins present in the sample, from all the organisms collected. Only the holoprotein is going to be detected. The unique immunochemical method (western blot) used to until now is not very accurate, but immunological methods are extremely sensitive, simple, specific and can be used as field tool. Antibodies recognise either apoprotein and holoprotein.

Endorreic lagoons are a very frequent phenomena in the arid areas of the Ebro Valley in Aragon (Spain). Several of these salty lagoons have been altered by dreanage channels or incorporation of residual waters from agriculture and farming.

In this work, three of these endorheic lagoons have been investigated concerning the potential iron stress of their phytoplanktonic population. One of the lagoons, «La Playa» (Bujaraloz, Zaragoza) remains unaltered, while the two others have been utilised as reservoir («La Estanca», Chiprana, Zaragoza) or modified by the construction of a drainage channel to maintain a constant level (Sariñena, Huesca) to avoid changes due to irrigation excedents affluents. The aim of this work is not to pretend characterise the iron status of the 3 lagoons, but to give some insights about the use of biochemical tools in limnology. Iron stress can influence biomass and the diversity of the population of phytoplankton, and it is an important parameter which can be determined easily.

\section{Material and methods}

Flavodoxin for standards and antibody preparation, was isolated from iron-deficient cultures of Scenedesmus vacuolatus (formerly Chlorella fusca (Shihira et Kraus 211-15) obtained from the University of Göttingen (Germany) culture collection), according to Peleato et al. (1994). Ferredoxin was purified from the ironsufficient cells as described in Bes et al. (1999).

Samples were harvested in 5 sampling stations in each lagoon. $25 \mathrm{~L}$ were collected and filtered using $4 \mathrm{~mm}$ cheese cloth. The $25 \mathrm{~L}$ of water were centrifuged in a Beckmann J2-21 with a JCF-Z continuos flow rotor at $10000 \mathrm{x} \mathrm{g}$.

Conductivity was measured in 5 sampling stations in each lagoon with a Wissenschaftlich Technische Werkstätter LF-91 conductimetter previously callibrated. $\mathrm{pH}$ was measured in the same sampling stations using a Hanna pHEP HI-4840 and $\mathrm{pH}$ paper from PANREAC.

Cells were broken down using a Mini-Beadbeater from Biospec Products with $0.5 \mathrm{~mm}$ zirconium beads. $50 \mathrm{mM}$ Tris-acetate $\mathrm{pH} 8$, containing $5 \mathrm{mM} \mathrm{MgCl}$, $1 \mathrm{mM} \beta$-mercaptoethanol, $1 \mathrm{mM}$ EDTA and $10 \mu \mathrm{M}$
PMSF (phenylmethylsulfonyl fluouride) was used as the extraction buffer.

Total protein quantification was performed by the bicinchoninic acid method (Smith et al. 1985). Chlorophyll content was determined spectrophotometrically as described by MacKinney (1941).

Development of the ELISAs : Although both ELISAs were developed separately, the procedure is the same. As solid support we use Maxisorp (Nunc) plates. Antibodies were obtained according to Bes et al. (1999) for ferredoxin, and Peleato et al. (1994) for flavodoxin. The unlabelled antibody (anti-ferredoxin or flavodoxin) was added to the bottom of each well by adding $50 \mu \mathrm{l}$ of antibody solution. This antibody solution has a concentration of $40 \mu \mathrm{g} / \mathrm{ml}$ of antibody antiferredoxin or $60 \mu \mathrm{g} / \mathrm{ml}$ of antibody anti-flavodoxin in $0.1 \mathrm{M}$ carbonate/ sodium bicarbonate $\mathrm{pH} 9.6$ buffer. The plates and the antibodies were incubated for 2 hours at room temperature in a humid atmosphere. After that, the wells were washed three times with $0.01 \mathrm{M}$ phosphate $\mathrm{pH} 7.4(400 \mu \mathrm{l} /$ well), with $0.15 \mathrm{M}$ $\mathrm{NaCl}$. The wells were filled to the top with blocking buffer $(400 \mu \mathrm{l} /$ well). $0.01 \mathrm{M}$ buffer phosphate $\mathrm{pH} 7.4$, with $0.15 \mathrm{M} \mathrm{NaCl}$, with $3 \%(\mathrm{w} / \mathrm{v})$ bovine albumin and $0.01 \%(\mathrm{w} / \mathrm{v})$ sodium ethylmercurithiosalicylate, was used as blocking buffer. The plates were incubated overnight at room temperature in a humid atmosphere. The wells were washed three times with $0.01 \mathrm{M}$ phosphate $(400 \mu \mathrm{l} /$ well) $\mathrm{pH} 7.4$, with $0.15 \mathrm{M} \mathrm{NaCl}$, before adding $50 \mu \mathrm{l}$ of the antigen (standards and samples) to the wells. Once the plates had been incubated for 2 hours at room temperature in a humid atmosphere, the wells were washed three times with $400 \mu \mathrm{l} /$ well with $0.01 \mathrm{M}$ phosphate $\mathrm{pH} 7.4$, with $0.15 \mathrm{M} \mathrm{NaCl}$. The labelled second antibody, prepared according to Ternynck \& Avrameas (1989) was added, with anti-flavodoxin at $4.5 \mu \mathrm{g} / \mathrm{ml}$ and anti-ferredoxin at $11 \mu \mathrm{g} / \mathrm{ml}$. The reaction mixture was incubated for 2 hours at room temperature in a humid atmosphere, and the wells were washed four times with $400 \mu \mathrm{l} /$ well $0.01 \mathrm{M}$ phosphate $\mathrm{pH} 7.4$, with $0.15 \mathrm{M} \mathrm{NaCl}$. The formation of the coloured enzyme product was started by adding $100 \mu l$ of peroxidase substrate $\left(3,3^{\prime}, 5,5^{\prime}\right.$-tetramethylbencidine ( $k$-blue, Neogen)) to the wells. The enzyme reaction should be stopped after $30 \mathrm{~min}$ by adding $100 \mu \mathrm{l}$ of $1 \mathrm{M} \mathrm{HCl}$. Using the mentioned peroxidase substrate, absorbance at $450 \mathrm{~nm}$ of standards and samples was recorded, and used for quantification.

Iron content in the samples was determined after filtering an aliquot of water with a $0.4 \mu \mathrm{m}$ pore filter. Iron was determined by atomic absorption at the Servicios Cientifico-Técnicos at Barcelona University. 


\section{Results and discussion}

These ELISA tests have been developed for the proteins from a green algae, Scenedesmus vacuolatus. As all immunological test, only proteins from this organism or very related are going to be recognised by the antibodies. $S$. vacuolatus is one of the few eukaryotic organisms with flavodoxin induction, with the antibodies against flavodoxin, ferredoxin no cross-reactive with proteins from diatoms, cyanobacteria or heterotrophic bacteria as Azotobacter (Inda \& Peleato 2002).

Samples were harvested the 29 August, 1999. Table 1 show the physico-chemical parameters determined at the time of the sample recollection. Conductivity was fairly low in «Sariñena» lagoon, and the very high pH is congruent with the low amount of iron found in solution since at alkaline conditions iron is mainly as insoluble hydroxides. In spite of the low iron concentration, $0.8 \mathrm{~g}$ fresh weight per litter of water were harvested. Visual observation, using optical microscope, indicate that the predominan population were filamentous cyanobacteria.

In the «La estanca» lagoon was much less biomass : $0.015 \mathrm{~g} / \mathrm{L}$ (fresh weight) (Table 1). In this case the po- pulation was very heterogeneous. Conductivity still not very high, and the $\mathrm{pH}$ lower than 8 permits the existence of soluble forms of iron, as was found.

«La Playa» is a salty lagoon, with very high conductivity (Table 1). Martinez et al. (1990) described the predominant presence of $\mathrm{NaCl}$ and $\mathrm{Mg}_{2} \mathrm{Cl}$. Only halophytes are going to survive at such conditions. The $\mathrm{pH}$ also is alkaline, and the iron found was below $35 \mathrm{nM}$. $0.019 \mathrm{~g} / \mathrm{L}$ of fresh weight of cells were harvested from the sample. Cyanobacteria and diatoms were the predominant organisms.

$0.2 \mathrm{~g}$ of cells were broken and after centrifugation, crude extracts were use for flavodoxin and ferredoxin immunoquantification, as well as total chlorophyll and protein determination. Table 2 show the values of flavodoxin and ferredoxin determined using the two ELISA tests. The phytoplankton from «Sariñena» lagoon has a light iron deficiency, indicated by the presence of small amounts of flavodoxin. The flavodoxin index in low despite of a low iron concentration in water. This data is congruent with the high biomass present in the samples, non possible in a limited environment. An important detail is that the population of this lagoon is

Table 1. Some physico-chemical parameters of the lagoons. Iron was determined after $0.4 \mu \mathrm{m}$ filtration of the sample. Values are means of 3 determinations.

Tableau 1. Paramètres physico-chimiques des lagunes. La quantité de fer est déterminée après filtration de l'échantillon sur un filtre de $0.4 \mu \mathrm{M}$. (3 déterminations).

\begin{tabular}{cccc}
\hline Lagoon & $\begin{array}{c}\text { Conductivity } \\
\mathrm{mS} / \mathrm{cm}\left({ }^{\circ} \mathrm{C}\right)\end{array}$ & $\mathrm{pH}$ & Iron $(\mu \mathrm{M})$ \\
\hline Sariñena & $2.46\left(29^{\circ} \mathrm{C}\right)$ & 9.96 & less than 0.035 \\
«La Estanca» & $4.55\left(28^{\circ} \mathrm{C}\right)$ & 7.68 & $0.730 \pm 0.02$ \\
«La playa» & $17.9\left(27^{\circ} \mathrm{C}\right)$ & 8.48 & less than 0.035 \\
\hline
\end{tabular}

Table 2. Flavodoxin and ferredoxin immunoquantified by ELISA, and the calculated Flavodoxin Index. Total chlorophyll content present in the crude extracts is also presented. All values are given as to $\mathrm{mg}$ of soluble proteins present in the crude extracts. Values are means of 3 determinations, presented with standard deviation.

Tableau 2. Flavodoxine et ferredoxine immunoquantifiées par le test ELISA et l'index calculé de la flavodoxine. La quantité totale de chlorophylle présente dans l'extrait cru est aussi reportée. Toutes les valeurs sont exprimées en mg de protéines solubles présentes dans l'extrait frais. (3 déterminations).

\begin{tabular}{ccccc}
\hline Lagoon & Fld (nmol/mg) & Fd $(\mathrm{nmol} / \mathrm{mg})$ & $\mathrm{I}_{\text {fld }}(\%)$ & chlorophyll $(\mathrm{mg} / \mathrm{mg})$ \\
\hline Sariñena & $0.5 \pm 0.05$ & $24.2 \pm 0.9$ & 2 & 0.034 \\
«La Estanca» & $193.5 \pm 7.2$ & $41.4 \pm 4.1$ & 82.5 & 0.057 \\
«La playa» & $6.64 \pm 0.7$ & $6.15 \pm 0.6$ & 52 & 0.026 \\
\hline
\end{tabular}


totally dominated by cyanobacteria, and cyanobacteria have a very efficient iron uptake systems, based in siderophore excretion (Strauss 1994).

«La Estanca», with apparently more iron in solution, $0.73 \mu \mathrm{M}$ (Table 2), showed a Flavodoxin Index (82 \%) which indicates a severe iron deficiency. However, 0.73 $\mu \mathrm{M}$ or iron is a concentration considered in laboratory conditions as deficient. In controlled $\mathrm{pH}$ conditions and using the Kessler \& Czygan (1970) culture media, Inda \& Peleato (2002) measured Flavodoxin Index for S.vacuolatus at different iron concentrations. At $0.73 \mu \mathrm{M}$ iron the calculated one ranged about $33 \%$, but as state previously, the direct measure of iron does not indicate the availability of the metal, and other parameters of the environment can affect strongly the biodisponibility of the iron for the cells. Taking in account the high amount of flavodoxin synthesised, the phytoplankton present in the lagoon «La Estanca» appears to be iron-stressed». Fresh weight obtained from the sample is congruent with the predicted limitation of iron.

«La Playa» is a salty lagoon with a high conductivity, $\mathrm{pH}$ alkaline and consequently very low amount of iron in solution. In this case, the Flavodoxin Index is $52 \%$ (Table 2), a little less than expected from the iron detemined by atomic absorption in the water, after removal of particulate matter. The cells are obviously iron-stressed, but the amount of ferredoxin is more or less the same than flavodoxin. The obtained data is congruent with previous work in our laboratory (Inda \& Peleato 2002), since we found that salt stress can modify the relative amount of flavodoxin and ferredoxin, changing the Flavodoxin Index. For this reason, in salty waters it is important to know that Flavodoxin Index should be take with precaution. The field data presented in Table 2 confirm the laboratory observations, even though the model organism used, S.vacuolatus is not halotolerant, and the behaviour could be different in the population present in «La Playa» lagoon.

ELISA test is an immunoenzymatic assay which is easy to use, very fast and very sensitive. This powerful technique can be extrapolated easily to marine environments, using proteins from model marine organisms, with well typified response to iron stress. Iron supply affects phytoplankton biomass, growth rate and species composition as well as primary productivity in surface waters, and it is a chemical parameter to be taken in account for limnologist.

\section{Acnowledgements}

L.A.I. thanks the Comunidad Foral de Navarra for a fellowship.

\section{References}

Behrenfeld M.J., Bale A.J., Kolber Z.S., Aiken J. \& Falkowski P.J. 1996. - Confirmation of iron limitation of phytoplankton photosynthesis in the equatorial Pacific Ocean. Nature, $383: 508-511$.

Bes M.T., Parisini E., Inda L.A., Saraiva L.M., Peleato M.L. \& Sheldrick G. 1999. - Crystal structure determination at 1.4 A resolution of ferredoxin from the green algae Chlorella fusca. Structure, 7: 1201-1211.

Coale K.H., Johnson K.S., Fitzwater S.E., Gordon R.M., Tanner S., Chavez F.P., Ferioli L., Sakamoto C., Rogers P., Millero F., Steinberg P., Nightingale P., Cooper D., Cochlan W.P., Landry, M.R., Constaninou J., Rollwagen G., Trasvina A. \& Kudela R. 1996. A massive phytoplankton bloom induced by an ecosystem-scale iron fertilization experiment in equatorial Pacific Ocean. Nature, 383: 495-501.

Doucette G.J., Erdner D.L., Peleato M.L, Hartman J.J. \& Anderson, D.M. 1996. - Quantitative analysis of iron-stress related proteins in Thalassiosira weisslogii : measuremente of flavodoxin and ferredoxin using HPLC. Mar. Ecol. Prog. Ser, 130 : 269-276.

Entsch B., Sim R.G. \& Hatcher B.G. 1983. - Indications from photosynthetic components that iron is a limiting nutrient in primary producers on coral reefs. Mar. Biol., 73 : 17-30.

Frost B.W. 1996. - Phytoplankton bloom on iron rations. Nature, $383: 475-476$

Inda L.A. \& Peleato M.L. 2002. - Immunoquantification of flavodoxin and ferredoxin from Scenedesmus vacuolatus as iron stress molecular markers. Eur. J. Phycol., 37 : 486-492.

Kirchman D.L. 1996. - Microbial ferrous wheel. Nature, 383 : 303-304.

Kessler E. \& Czygan F. C. 1970. - Physiologische und biochemische Beitrage zur Taxonomie der Gattung Chlorella. Arch. Mikrobiol., $70: 211-216$.

LaRoche J., Murray H., Orellana M. \& Newton J. 1995. - Flavodoxin expression as an indicator of iron limintation in marine diatoms. J. Phycol., 31 : 520-530.

LaRoche J., Boyd P.W., McKay M.L. \& Geider R.J. 1996. — Flavodoxin as an in situ marker for iron stress in phytoplankton. Nature, $382: 802-805$.

MacKinney G. 1941. - Absorption of light by chlorophyll solutions. J. Biol. Chem., $140: 314-322$.

Martinez F.J., Sánchez J.A., San Román J. \& De Miguel J.L. 1990. - Delimitacóin de zonas de interés ecológico-paisajistico en la zona regable de Bujaraloz : estudio de viabilidad hidrológica. Cátedra de Hidrogeología, Departamento de Ciencias de la Tierra, Universidad de Zaragoza.

Peleato M.L., Ayora S.., Inda L.A. \& Gómez-Moreno C. 1994. Isolation and characterization of two different flavodoxins from the eukaryote Chlorella fusca. Biochem. J., $302:$ 807-811.

Smith P.K., Krohn R.I., Hermanson G.T., Mallia A.K., Gartner F.H., Provenzano M.D., Fujimoto E.K., Goeke N.M., Olson B.J. \& Klenk D.C. 1985. - Measurement of protein using bicinchoninic acid. Anal. Biochem., 150:76-85.

Strauss N.A. 1994. - Iron deprivation : physiology and gene regulation. In The Molecular Biology of Cyanobacteria D.A. Bryant (ed) Kluwer Academic Pub. Netherlands.

Ternynck T. \& Avrameas S. 1989. - Técnicas inmunoenzimáticas. Grupo Editorial Iberoamericana. México.

Utkilen H. \& Gjolme N. 1995. - Iron-stimulated toxin production in Microcystis aeruginosa. Appl. Environ. Microbiol., 61 : 797-800. 